\title{
Identifikasi Kejadian Kekerasan pada Anak di Kota Malang
}

\section{Identification of Violence in Children in Malang City}

\author{
Thathit Manon Andini' ${ }^{1)}$, Tutik Sulistyowati' ${ }^{2)}$, Aini Alifatin ${ }^{3)}$, Rahmad Pulung Sudibyo ${ }^{4}$, \\ Wildan Suharso ${ }^{5)}$, Diana Savitri Hidayati ${ }^{6}$, Dini Kurniawati ${ }^{7)}$, Nur Hayatin ${ }^{8)}$, Erna Retna \\ Rahadjeng $^{9}$, Dyah Worowirastri Ekowati ${ }^{10}$
}

1,2,3,4,5,6,7,8.9.10) Lembaga Pengkajian Dan Pemberdayaan Perempuan dan Anak, Universitas Muhammadiyah Malang, Jln. Raya Tlogomas no. 246, Malang 65144. Email : thathit@ umm.ac.id.

Abstrak: Tujuan dari penelitian ini adalah untuk mengidentifikasi kekerasan yang dihadapi oleh siswa sekolah dasar di Kota Malang. Jenis pelecehan adalah penganiayaan fisik, pelecehan verbal, pelecehan emosional, dan pelecehan seksual. Desain penelitian yang digunakan dalam penelitian ini adalah penelitian deskriptif. Pelajaran dari penelitian ini adalah siswa sekolah dasar di kelas 3, 4, 5 dan 6, khususnya di Sekolah Dasar Muhammadiyah di Kota Malang. Dengan menggunakan sampel acak sebanyak 347 siswa sebagai sampel, diketahui adanya pelecehan siswa. pelecehan fisik, pelecehan verbal, pelecehan emosional, dan pelecehan seksual. Berdasarkan usia, siswa yang menerima pelecehan berusia sekitar 8 tahun (14\%), 9 tahun (23\%), 10 tahun (31\%), 11 tahun (21\%), 12 tahun (8\%), dan $13(3 \%)$. Penelitian dilakukan pada bulan Agustus 2017. Instrumen yang digunakan adalah kuesioner terpimpin. Artinya para peneliti masih memberikan panduan kepada anak bagaimana menjawab pertanyaan dengan considering bahwa mereka masih kekurangan pengetahuan mengisi kuesioner. Hasil penelitian menunjukkan bahwa bentuk kekerasan yang diterima responden adalah kekerasan fisik, kekerasan verbal, kekerasan emosional dan kekerasan seksual. Ditemukan bahwa anak-anak yang mengalami kekerasan dalam rentang 9 tahun (23\%), 10 tahun $(31 \%)$, dan 11 tahun $(21 \%)$. Berdasarkan kondisi keluarga, anak-anak yang sering menghadapi kekerasan tersebut kebanyakan adalah satu-satunya anak di keluarga sampai tiga bersaudara (23-30\%). Ibu dari anakanak yang sering menerima pelecehan kekerasan tersebut adalah keluarga dengan istri tanpa penghasilan, pekerja atau karyawan. Kondisi stres memaksa ibu melakukan kekerasan kepada anak mereka. Dari sisi profesi ayah, anak-anak yang menerima penganiayaan tersebut, ayah mereka adalah ayah yang bekerja sebagai staf di sebuah perusahaan, pengangguran, berpenyakitan, kondisi rumah yang buruk, ukuran keluarga yang lebih besar daripada rata-rata, kehadiran bayi baru, dan cacat. Yang kedua, bentuk kekerasan verbal terjadi saat pelaku menerapkan komunikasi yang mengandung tentang penghinaan, atau perkiraan anak-anak. Dalam penelitian ini, sebagian besar kekerasan yang diterima oleh responden adalah marah (36\%), menggerutu (20\%), disebut dengan kata2 buruk (9\%), bentakan (8\%), dan selalu disalahkan (7\%). kekerasan seperti marah, menggerutu adalah cara bagaimana orang tua ingin mendidik anak mereka. Semua kekerasan tersebut disebabkan oleh keinginan orang tua agar mereka ingin membuat anak-anak mereka menjadi lebih rajin, disiplin dan menjadi anak-anak yang baik. Bisa dikatakan, berdasarkan temuan bahwa kekerasan ini tidak serius bagi mereka.

Kata kunci: Kekerasan, anak-anak, fisik, emosional, verbal dan seksual, hati-hati

Abstract: The aims of this research is to identify the Children abuse faced by the elementary students in Malang City. The research design used in this research is descriptive research. The population of this research were the students of elementary school in 3,4,5 and 6 grade, specifically in Muhammadiyah Elementary School in Malang City.By using random sampling with 347 students as sample, it was identified that there the students' abuse covers physical abuse, verbal abuse, emotional abuse, and sexual abuse. Based on the age, the students who received the abuse are around 8 years old (14\%), 9 years old (23\%), 10 years old (31\%), 11 years old (21\%), 12 years old (8\%), and $13(3 \%)$. The research was conducted on August 2017. The instruments used are the guided questionnaire. It means that the researchers still give 
the guidance to the children how to answer the question with the considering that they still lack of knowledge filling the questionnaire.

The result of the research show that the form of abuse the respondents received are physical abuse, verbal abuse, emotional abuse and sexual abuse. It was found that the children who experienced the abuse in the range of 9 years old (23\%), 10 years old (31\%), and 11 years old (21\%). Based on the family condition, the children who often face the abuse is mostly the only children in the family up to three brothers and sisters (23-30\%). The mother of the children who often receive the abuse is home wife without income, the company workers or staff. Stressful condition force the mother do the abuse to their children. In the side of father profession, the children who received the abuse, they belong to the father who works as a staff in a company, unemployment, illness, poorhouse condition, a large than average family size, the presence of a new baby, and disable.

Keywords: Abuse; children; physical; emotional; verbal and sexual; beware

\section{PENDAHULUAN}

Indonesia sudah benar-benar berada pada kondisi gawat darurat anak. Kasus kekerasan terhadap anakanak di Indonesia beberapa tahun ini meningkat dengan sangat tajam. Hasil Survei Kekerasan Terhadap Anak Tahun 2013 yang dilakukan oleh KPP-PA bekerjasama dengan Kemensos dan BPS menemukan pada kelompok umur 18-24 tahun, menunjukkan sebesar 1 dari 2 laki-laki dan 1 dari 6 perempuan setidaknya mengalami salah satu kekerasan seksual, fisik atau emosional. Data Komnas PA pada tahun 2013 terdapat terdapat 1620 kasus kekerasan terhadap anak : 490 (30\%) kekerasan fisik, 313 (19\%) kekerasan emosional, 817 (51 \%) kekerasan seksual.Data-data tersebut diatas hanyalah data mengenai kasus-kasus yang diungkap oleh pihak kepolisian, jumlah sesungguhnya kasus yang tidak maupun belum terungkap bisa jadi jauh lebih besar lagi.

Anak adalah generasi penerus bangsa, anak merupakan investasi keluarga, anak bagaimanapun kondisinya menjadi harapan bagi masa depan. Anak, apapun kondisinya, memerlukan perhatian yang sama seperti anak lain, banyak cinta dan kasih sayang. Anak kecil perlu digendong, diajak bermain, dicium, dipeluk, diberi makan, dan dininabobokan supaya tidur. Saat tumbuh, anak-anak perlu bermain, mempunyai teman, dan pergi ke sekolah, sama halnya seperti anak lain. Ketiadaan akses untuk mendapatkan ruang bermain seperti ini akan berpengaruh terhadap optimalisasi pertumbuhan dan perkembangan anak dalam masyarakat. (Momon S, 2008). Jika anak tidak mendapatkan pengasuhan yang baik selama masa tumbuh kembangnya, maka anak tidak dapat bertumbuh dan berkembang dengan optimal sehingga lahirlah penerus bangsa yang cacat baik fisik, mental, intelektual, sosial maupun spiritual.

Dampak dari perlakuan kekerasan pada anak justru menimbulkan trauma dan menyisakan abnormalitas tumbuh kembang yang akan mempengaruhi dewasanya kelak. Terbukti bahwa saat ini pelaku kekerasan bukan hanya dilakukan orang dewasa, terbukti berdasarkan data dari Ditjen Pemasyarakatan, Kemenkumham pada bulan Agustus 2014 Anak yang Berhadapan dengan Hukum meliputi: Jumlah tahanan anak sebanyak 1.441 anak, terdiri dari anak laki-laki sebanyak 1.409 anak dan anak perempuan sebanyak 32 anak. Jumlah narapidana anak sebanyak 3.154 anak, terdiri dari anak laki-laki sebanyak 3.096 anak dan anak perempuan sebanyak 58 anak. Selanjutnya, hal ini menimbulkan pertanyaan khusus, apakah penjara adalah tempat yang baik dan benar bagi proses pendidikan, pertumbuhan dan perkembangan anak?

Banyak pola asuh yang secara sadar atau tidak sadar menempatkan orang tua sebagai sosok yang otoriter, pembuat peraturan tunggal, mengancam, menghukum bila anak melakukan kesalahan. Akibatnya anak menjadi takut, segan atau tidak berani bercerita secara terbuka terhadap apa yang diinginkan atau dialaminya. Anak yang sering mendapatkan kekerasan, baik dari orang terdekat maupun orang asing, seringkali sekaligus mendapat ancaman dan larangan untuk tidak menyampaikan pada orang lain. Fenomena gunung es pada kasus kekerasan seksual juga terjadi akibat korban tidak berani melapor, atau hanya satu yang melapor, tetapi dibelakangnya ada 6 korban bahkan lebih yang tidak melapor.

Berbagai faktor yang melatar belakangi terjadinya kekerasan telah banyak diteliti. Tidak adanya kontrol sosial merupakan pencetus terabaikannya kekerasan pada anak. Anak yang mendapat hukuman dari orang tua, dianggap sesuatu yang biasa terjadi antara anak dengan orang tua. Tetangga atau siapapun yang tidak akan melaporkan hukuman tersebut sebagai kekerasan kecuali anak sampai meninggal atau cedera 
berat. Hubungan anak dengan orang dewasa berlaku seperti hirarki sosial di masyarakat. Anak tidak boleh membantah apa yang dilakukan oleh orang tua. Ayah menghukum anak, guru menghukum siswa, menjadikan anak sebagai makhluk yang lebih rendah dan bukan makhluk yang memiliki hak dan kehendak. struktur ekonomi dan politik yang menindas, telah melahirkan subkultur kekerasan. Karena tekanan ekonomi, orang tua mengalami stres yang berkepanjangan. dia menjadi sangat sensitif. dia mudah marah. Kelelahan fisik tidak memberinya kesempatan untuk bercanda dengan anak-anak. Terjadilah kekerasan emosional, kekerasan verbal, kekerasan fisik. Orang tua bisa memaksa anak melakukan pekerjaan berat, atau menjual anaknya ke agen prostitusi karena tekanan ekonomi.

Doktor Tabatabaei, seorang pakar media di Iran, pernah menulis bahwa masa kanak-kanak merupakan salah satu tahapan usia seorang manusia, yang memiliki kebutuhan dan kapasitas tersendiri. Jiwa dan fisik anak-anak yang lembut tidak memiliki kesiapan untuk dihadapkan kepada konflik dan masalah yang dialami oleh orang dewasa. Neil Postman, seorang penulis Amerika, juga pernah menulis bahwa jika sudah tidak ada batas antara dunia anak-anak dan dunia orang dewasa, tidak akan ada lagi apa yang dinamakan sebagai dunia kanak-kanak. Anak bukanlah orang dewasa dalam ukuran mini. Mereka membutuhkan topangan, sokongan, dan perlindungan aktor "orang dewasa": yaitu keluarga, masyarakat, Pemerintah dan Negara. Perlindungan terhadap Anak haruslah merupakan segala kegiatan untuk menjamin dan melindungi anak dan hak-haknya agar dapat hidup, tumbuh, berkembang, dan berpartisipasi, secara optimal sesuai dengan harkat dan martabat kemanusiaan, serta mendapat perlindungan kekerasan dan diskriminasi, sebagaimana tercantum dalam UU No. 35 Th.2014 ttg Perubahan UU No.23 Th. 2002 tentang Perlindungan Anak.

Perlu upaya untuk menggali berbagai karakteristik yang dapat melatarbelakangi terjadinya kekerasan pada anak sehingga dapat diperoleh keterbukaan anak ketika mendapatkan kekerasan baik fisik, emosi, maupun seksual, sehingga semua perilaku yang berpotensi melecehkan anak dan berbagai peristiwa kekerasan pada anak dapat diantisipasi.

\section{KAJIAN PUSTAKA \\ Kekerasan}

Kekerasan berarti penganiayaan, penyiksaan atau perlakuan salah. Menurut WHO (dalam bagong S, dkk, 2000), kekerasan adalah penggunaan kekuatan fisik dan kekuasaan, ancaman atau tindakan terhadap diri sendiri, perorangan atau sekelompok orang atau masyarakat yang mengakibatkan atau kemungkinan besar mengakibatkan memar/trauma, kematian, kerugian psikologis, kelainan perkembangan atau perampasan hak.

Awal mulanya istilah tindak kekerasan pada anak atau child abuse dan neglect dikenal dari dunia kedokteran, sekitar tahun 1946, caffey-seorang radiologist melaporkan kasus cedera yang berupa gejalagejala klinik seperti patah tulang panjang yang majemuk (multiple fractures) pada anak-anak atau bayi disertai perdarahan subdural tanpa mengetahui sebabnya (unrecognized trauma). Dalam dunia kedokteran. Istilah ini dikenal dengan istilah Caffey Syndrome (Ranuh, 1999)

Barker (dalam hurairah, 2007) mendefinisikan Child abuse merupakan tindakan melukai berulang-ulang secara fisik dan emosional terhadap anak yang ketergantungan, melalui desakan hasrat, hukuman badan yang tidak terkendali, degradasi dan cemoohan permanen atau kekerasan seksual.

1. Bentuk-bentuk kekerasan pada anak

Menurut moore (dalam Nataliani, 2004), kekerasan atau perlakuan salah terhadap anak pada umumnya dapat diklasifikasikan dalam tiga kategori, antara lain kekerasan fisik, seksual dan emosional. Purbani (2003) mengatakan, kekerasan dalam rumah tangga baik dilakukan oleh suami kepada istrinya atau orang tua terhadap anaknya bisa berbentuk fisik dan non fisik. Kekerasan non fisik bisa berbentuk verbal seperti pelecehan, penghinaan, mencuekin (mendiamkan) istri atau anak, atau bentuk lain seperti tidak membiayai selama berbulan-bulan, sedangkan kekerasan fisik bisa berbentuk pemukulan, penjambakan, dll.

Terry E. Lawson (dalam huraerah, 2007), psikiater internasional yang merumuskan definisi tentang Child Abuse, menyebut ada empat macam abuse, yaitu emotional abuse, verbal abuse, physical abuse, dan sexual abuse) 
a. Kekerasan secara fisik (Physical abuse)

1) Pengertian Physical abuse

Physical abuse, terjadi ketika orang tua/pengasuh dan pelindung anak memukul anak (ketika anak sebenarnya memerlukan perhatian). Pukulan akan diingat anak itu jika kekerasan fisik itu berlangsung dalam periode tertentu. Kekerasan yang dilakukan seseorang berupa melukai bagian tubuh anak.

Segala bentuk penyiksaan fisik terjadi ketika frustasi atau marah, kemudian melakukan tindakantindakan agresif secara fisik, dapat berupa cubitan, pukulan, tendangan, menyulut dengan rokok, membakar dan tindakan-tindakan lain yang dapat membahayakan anak. Sangat sulit dibayangkan bagaimana orang tua dapat melukai anaknya, seringkali penyiksaan fisik adalah hasil dari hukuman fisik yang bertujuan menegakkan disiplin, yang tidak sesuai dengan usia anak. Banyak orang tua ingin menjadi orang tua yang baik, tapi lepas kendali dalam mengatasi perilaku anak.

2) Efek

Efek penyiksaan fisik yang berulang-ulang dalam jangka waktu lama akan menimbulkan cedera serius terhadap anak, meninggalkan bekas baik fisik maupun psikis, anak menjadi menarik diri, merasa tidak aman, sukar mengembangkan trust kepada orang lain, perilaku merusak, dll. Bila kejadian ini berulang maka proses recoverynya membutuhkan waktu yang lebih lama pula.

b. Kekerasan emosional (emotional abuse)

1) Pengertian

Emotional abuse atau penyiksaan emosi terjadi ketika orang tua/pengasuh dan pelindung anak setelah mengetahui anaknya meminta perhatian, mengabaikan anak itu. Ia membiarkan anak basah atau lapar karena ibu terlalu sibuk atau tidak ingin diganggu waktu itu. Ia boleh jadi mengabaikan kebutuhan anak untuk dipeluk atau dilindungi. Anak akan mengingat semua kekerasan emosional jika kekerasan emosional itu berlangsung konsisten. Orang tua yang secara emosional berlaku keji pada anaknya akan terus menerus melakukan hal yang sama sepanjang kehidupan anak itu. Kekerasan emosi juga disebut sebagai penyiksaan emosi.

Penyiksaan emosi adalah semua tindakan merendahkan atau meremehkan orang lain. Jika hal ini menjadi pola perilaku maka akan mengganggu proses perkembangan anak selanjutnya. Hal ini dikarenakan konsep diri anak terganggu, selanjutnya anak merasa tidak berharga untuk dicintai dan dikasihi. Anak yang terus menerus dipermalukan, dihina, diancam atau ditolak akan menimbulkan penderitaan yang tidak kalah hebatnya dari penderitaan fisik.

Bagi yang menderita deprivasi (kekurangan) kebutuhan dasar emosional, meskipun secara fisik terpelihara dengan baik, biasanya tidak bisa bertahan hidup. Deprivasi emosional tahap awal akan menjadikan bayi tumbuh dalam kecemasan dan rasa tidak aman, dimana bayi lambat perkembangannya, atau akhirnya mempunyai rasa percaya diri yang rendah.

2) Jenis-jenis penyiksaan emosi adalah :

a) Penolakan

Orang tua mengatakan kepada anak bahwa dia tidak diinginkan, mengusir anak atau memanggil anak dengan sebutan yang kurang menyenangkan. Kadang anak menjadi kambing hitam segala problem yang ada dalam keluarga.

b) Tidak diperhatikan

Orang tua yang mempunyai masalah emosional biasanya tidak dapat merespon kebutuhan anak-anak mereka. Orang tua jenis ini mengalami problem kelekatan dengan anak. Mereka menunjukkan sikap tidak tertarik pada anak, sukar memberi kasih saying, atau bahkan tidak menyadari akan kehadiran anaknya. Banyak orang tua yang secara fisik selalu ada disamping anak tetapi secara emosi sama sekali tidak memenuhi kebutuhan emosional anak.

c) Ancaman

Orang tua mengkritik, menghukum atau bahkan mengancam anak. Dalam jangka panjang keadaan ini mengakibatkan anak terlambat perkembangannya, atau bahkan terancam kematian

d) Isolasi 
Bentuknya dapat berupa orang tua tidak mengijinkan anak mengikuti kegiatan bersama teman sebayanya atau bayi dibiarkan dalam kamarnya sehingga kurang mendapat stimulasi dari lingkungan, anak dikurung atau dilarang makan sesuatu sampai waktu tertentu.

e) Pembiaran

membiarkan anak terlibat penyalahgunaan obat dan alkohol, berlaku kejam terhadap binatang, melihat tayangan porno, atau terlibat dalam tindak kejahatan seperti mencuri, berjudi, berbohong dan sebagainya. Untuk anak yang lebih kecil, membiarkannya menonton adeganadegan kekerasan dan tidak masuk akal di televisi termasuk juga dalam kategori penyiksaan emosi.

3) Efek penyiksaan emosi

Penyiksaan emosi sukar diidentifikasi atau didiagnosa karena tidak meninggalkan bekas yang nyata seperti penyiksaan fisik. Dengan begitu usaha untuk menghentikannya juga tidak mudah. Jenis penyiksaan ini meninggalkan bekas yang tersembunyi yang termanifestasikan dalam beberapa bentuk seperti kurang percaya diri, kesulitan membina persahabatan, perilaku merusak seperti tiba-tiba membakar barang atau bertindak kejam terhadap binatang, beberapa melakukan agresi, menarik diri, penyalahgunaan obat dan alkohol, ataupun kecenderungan bunuh diri.

c. Kekerasan secara verbal (verbal abuse)

Biasanya berupa perilaku verbal dimana pelaku melakukan pola komunikasi yang berisi penghinaan, ataupun kata-kata yang melecehkan anak. Pelaku biasanya melakukan tindakan mental abuse, menyalahkan, melabeli, atau juga mengkambing hitamkan.

d. Kekerasan seksual (sexual abuse)

1) Pengertian

Sexual abuse meliputi pemaksaan hubungan seksual yang dilakukan terhadap orang yang menetap dalam lingkup rumah tangga tersebut (seperti istri, anak, dan pekerja rumah tangga). Selanjutnya dijelaskan bahwa sexual abuse adalah setiap perbuatan yang berupa pemaksaan hubungan seksual, pemaksaan hubungan seksual dengan orang lain untuk tujuan komersial dan atau tujuan tertentu.

2) Jenis Kekerasan seksual

Kekerasan seksual (sexual abuse) merupakan jenis penganiayaan yang biasanya dibagi dalam kategori berdasar identitas pelaku (Tower, 2002), terdiri dari :

a) Familial abuse

Incest merupakan sexual abuse yang masih dalam hubungan darah, menjadi bagian dalam keluarga inti. Seseorang yang menjadi pengganti orang tua, misalnya ayah tiri, atau kekasih, termasuk dalam pengertian incest. Mayer (dalam Tower, 2002) menyebutkan kategori incest dalam keluarga dan mengaitkan dengan kekerasan pada anak. Kategori pertama, sexual molestation (penganiayaan). Hal ini meliputi interaksi noncoitus, petting, fondling, exhibitionism dan voyeurism, semua hal yang berkaitan dengan menstimulasi pelaku secara seksual. Kategori kedua, sexual assault (perkosaan), berupa oral atau hubungan dengan alat kelamin, masturbasi, fellatio (stimulasi oral pada penis), dan cunnilingus (stimulasi oral pada klitoris). Kategori terakhir yang paling fatal disebut forcible rape (perkosaan secara paksa), meliputi kontak seksual. Rasa takut, kekerasan, dan ancaman menjadi sulit bagi korban. Mayer mengatakan bahwa paling banyak ada dua kategori terakhir yang menimbulkan trauma terberat bagi anak-anak, namun korban-korban sebelumnya tidak mengatakan demikian. Mayer berpendapat derajat trauma tergantung pada tipe dari kekerasan seksual, korban dan survivor mengalami hal yang sangat berbeda. Survivor yang mengalami perkosaan mungkin mengalami hal yang berbeda dibanding korban yang diperkosa secara paksa.

b) Extrafamilial abuse

Extrafamilial abuse, dilakukan oleh orang lain diluar keluarga korban, dan hanya $40 \%$ yang melaporkan peristiwa kekerasan. Kekerasan seksual yang dilakukan oleh orang dewasa disebut pedophile, yang menjadi korban utamanya adalah anak-anak. Pedophilia diartikan "menyukai anak-anak"(de yong dalam Tower, 2002). Pedetrasy merupakan hubungan seksual antara pria 
dewasa dengan anak laki-laki (struve \& Rush dalam Tower, 2002). Pornografi anak menggunakan anak-anak sebagai sarana untuk menghasilkan gambar, foto, slide, majalah, dan buku (o'brien, Trivelpiece, pecora et al., dalam tower, 2002). Biasanya ada tahapan yang terlihat dalam melakukan kekerasan seksual. Kemungkinan pelaku mencoba perilaku untuk mengukur kenyamanan korban. Jika korban menuruti, kekerasan kekerasan akan berlanjut dan intensif, berupa :

1. Nudity (dilakukan oleh orang dewasa)

2. Disrobing (orang dewasa membuka pakaian di depan anak)

3. Genital exposure (dilakukan oleh orang dewasa)

4. Observation of the child (saat mandi, telanjang, dan saat membuang air)

5. Mencium anak yang memakai pakaian dalam

6. Fondling (meraba-raba dada korban, alat genital, paha dan bokong)

7. Masturbasi

8. Fellatio (stimulasi pada penis, korban atau pelaku sendiri)

9. Cunnilingus (stimulasi pada vulva atau area vagina, pada korban atau pelaku)

10.Digital penetration (pada anus atau rectum)

11.Penile penetration (pada vagina)

12.Digital penetration (pada vagina)

13.Penile penetration (pada anus atau rectum)

14.Dry intercourse (mengelus-elus penis pelaku atau area genital lainnya, paha, atau bokong korban) (sgroi dalam Tower, 2002)

3) Efek pelecehan seksual

Banyak sekali pengaruh buruk yang ditimbulkan dari pelecehan seksual. Pada anak yang masih kecil dan yang biasanya tidak mengompol jadi mengompol, mudah merasa takut, perubahan pola tidur, kecemasan tidak beralasan, atau bahkan symptom fisik seperti sakit perut atau adanya masalah kulit, dll. Pada remaja, mungkin secara tidak diduga menyulut api, mencuri, melarikan diri dari rumah, mandi terus menerus, menarik diri dan menjadi pasif, menjadi agresif dengan teman kelompoknya, prestasi belajar menurun, terlibat kejahatan, penyalahgunaan obat dan alkohol, dll. Sitohang (2004) menambahkan, bentuk-bentuk kekerasan selain kekerasan fisik, emosional, seksual juga penelantaran anak/pengabaian.

a. Pengertian penelantaran anak/pengabaian anak

Pengabaian terhadap anak termasuk penyiksaan secara pasif, yaitu segala ketiadaan perhatian yang memadai baik fisik, emosi maupun sosial. Pengabaian anak banyak dilaporkan sebagai kasus terbesar dalam kasus penganiayaan terhadap anak dalam keluarga.

b. Jenis-jenis pengabaian anak

1) Pengabaian fisik merupakan kasus terbanyak, misalnya keterlambatan mencari bantuan medis, pengawasan yang kurang memadai, serta tidak tersedianya kebutuhan akan rasa aman dalam keluarga.

2) Pengabaian pendidikan terjadi ketika anak seakan-akan mendapat pendidikan yang sesuai padahal anak tidak dapat berprestasi secara optimal. Lama kelamaan hal ini dapat mengakibatkan prestasi sekolah yang semakin menurun.

3) Pengabaian secara emosi dapat terjadi misalnya ketika orang tua tidak menyadari kehadiran anak ketika "ribut" dengan pasangannya. Atau orang tua memberikan perlakuan kasih sayang yang berbeda diantara anak-anaknya.

4) Pengabaian fasilitas medis. Hal ini terjadi ketika orang tua gagal menyediakan layanan medis untuk anak meskipun secara finansial memadai. Dalam beberapa kasus orang tua memberi pengobatan tradisional dulu, jika belum sembuh barulah kembali ke layanan dokter.

c. Efek pengabaian anak

Pengaruh yang paling terlihat adalah kurangnya perhatian dan kasih sayang orang tua terhadap anak. Bayi yang dipisahkan dari orang tuanya dan tidak memperoleh pengganti pengasuh yang 
memadai, akan mengembangkan perasaan tidak aman, gagal mengembangkan perilaku akrab (Hurlock. 1990), dan selanjutnya akan mengalami masalah penyesuaian diri pada masa yang akan datang. Menurut Suharto (1997) mengelompokkan kekerasan pada anak meliputi :

a. Kekerasan anak secara fisik

Kekerasan secara fisik adalah penyiksaan, pemukulan dan penganiayaan terhadap anak, dengan atau tanpa menggunakan benda-benda tertentu, yang menimbulkan luka-luka fisik atau kematian pada anak. Bentuk luka dapat berupa lecet atau memar akibat persentuhan atau kekerasan benda tumpul, seperti bekas gigitan, cubitan, ikat pinggang, atau rotan. Dapat pula berupa luka bakar akibat bensin panas atau berpola akibat sundutan rokok atau setrika. Lokasi luka biasanya ditemukan pada daerah paha, lengan, mulut, pipi, dada, perut, punggung atau daerah bokong. Terjadinya kekerasan fisik pada anak umumnya dipicu oleh tingkah laku anak yang tidak disukai orang tuanya, seperti anak nakal atau rewel, menangis terus, minta jajan, buang air atau muntah di sembarang tempat, atau memecahkan barang berharga dan lain-lain.

b. Kekerasan anak secara psikis

Kekerasan secara psikis meliputi penghardikan, penyampaian kata-kata kasar dan kotor, memperlihatkan buku, gambar dan film pornografi pada anak. Anak yang mendapatkan perlakuan ini umumnya menunjukkan gejala perilaku maladaptive, seperti menarik diri, pemalu, menangis jika didekati, takut keluar rumah dan takut bertemu dengan orang lain.

c. Kekerasan anak secara seksual

Kekerasan seksual dapat berupa perlakuan pra kontak seksual antara anak dengan orang yang lebih besar (melalui kata, sentuhan, gambar visual, exhibitionism maupun perlakuan kontak seksual secara langsung antara anak dengan orang dewasa (incest, perkosaan, eksploitasi seksual)

d. Kekerasan anak secara sosial

Kekerasan secara sosial dapat mencakup penelantaran anak dan eksploitasi anak. Penelantaran anak adalah sikap dan perlakuan orang tua yang tidak memberikan perhatian yang layak terhadap proses tumbuh kembang anak. Misalnya anak dikucilkan, diasingkan dari keluarga, atau tidak diberikan pendidikan dan perawatan kesehatan yang layak. Eksploitasi anak menunjuk pada sikap diskriminatif atau perlakuan sewenang-wenang terhadap anak yang dilakukan keluarga dan masyarakat. Sebagai contoh, memaksa anak untuk melakukan sesuatu demi kepentingan ekonomi, sosial, atau politik tanpa memperhatikan hak-hak anak untuk mendapatkan perlindungan sesuai dengan perkembangan fisik, psikisnya dan status sosialnya . misalnya anak dipaksa untuk bekerja di pabrik-pabrik yang membahayakan dengan upah rendah dan tanpa peralatan yang memadai, anak dipaksa untuk angkat senjata, atau dipaksa melakukan pekerjaan-pekerjaan rumah tangga melebihi batas kemampuannya.

2. Faktor-faktor penyebab kekerasan pada anak

Gelles Richard J.(1982) mengemukakan bahwa kekerasan terhadap anak (Child Abuse) terjadi akibat kombinasi dari berbagai faktor, yaitu :

a. Pewarisan kekerasan antar generasi (Intergenerational transmission of violence)

Banyak anak belajar perilaku kekerasan dari orang tuanya dan ketika tumbuh menjadi dewasa mereka melakukan tindakan kekerasan kepada anaknya. Dengan demikian, perilaku kekerasan diwarisi (transmitted) dari generasi ke generasi. Studi-studi menunjukkan bahwa lebih kurang 30\% anak-anak yang diperlakukan dengan kekerasan menjadi orang tua yang bertindak keras pada anak-anaknya. Sementara itu, hanya 2 sampai 3 persen dari semua individu menjadi orang tua yang tidak memperlakukan kekerasan kepada anak-anaknya. Anak-anak yang mengalami perlakuan salah dan kekerasan mungkin menerima perilaku ini sebagai model perilaku mereka sendiri sebagai orang tua. Tetapi sebagian besar anak-anak yang diperlakukan dengan kekerasan tidak menjadi orang dewasa yang memperlakukan kekerasan kepada anak-anaknya

b. Stres sosial (social stress) 
Stres yang ditimbulkan oleh berbagai kondisi sosial meningkatkan risiko kekerasan terhadap anak dalam keluarga. Kondisi-kondisi ini mencakup pengangguran (unemployment), penyakit (illness), kondisi perumahan yang buruk (poor housing condition) ukuran keluarga besar dari rata-rata ( $a$ larger than average family size), kelahiran bayi baru (the presence of a new baby), orang cacat (disable person) di rumah. Dan kematian (the death) seorang anggota keluarga. Sebagian besar kasus dilaporkan tentang tindakan kekerasan terhadap anak berasal dari keluarga yang hidup dalam kemiskinan. Tindakan kekerasan terhadap anak juga terjadi dalam keluarga kelas menengah dan kaya. Tetapi tindakan yang dilaporkan lebih banyak di antara keluarga miskin karena beberapa alasan.

c. Isolasi sosial dan keterlibatan masyarakat bawah

Orang tua dan pengganti orang tua yang melakukan tindakan kekerasan terhadap anak cenderung terisolasi secara sosial. Sedikit sekali orang tua yang bertindak keras ikut serta dalam suatu organisasi masyarakat dan kebanyakan mempunyai hubungan yang sedikit dengan teman atau kerabat.

d. Struktur keluarga

Tipe-tipe keluarga tertentu memiliki risiko yang meningkat untuk melakukan tindakan kekerasan dan pengabaian kepada anak. Misalnya orang tua tunggal lebih memungkinkan melakukan tindakan kekerasan terhadap anak dibandingkan dengan orang tua utuh. Selain itu, keluarga-keluarga di mana baik suami atau istri mendominasi di dalam membuat keputusan penting, seperti di mana bertempat tinggal, pekerjaan apa yang mau diambil, bilamana punya anak, dan beberapa keputusan lainnya, mempunyai tingkat kekerasan terhadap anak yang lebih tinggi dibandingkan dengan keluargakeluarga yang suami-istri sama-sama bertanggung jawab atas keputusan-keputusan tersebut.

3. Faktor-faktor lain yang mempengaruhi besar/kecilnya dampak dari kekerasan

Disamping segala bentuk penganiayaan yang dialami anak sebagaimana tercantum di atas, ada beberapa hal yang ikut andil dalam besar/kecilnya dampak yang diderita anak, antara lain:

a. Faktor usia anak. Semakin muda usia anak maka akan menimbulkan akibat yang lebih fatal.

b. Siapa yang terlibat. Jika yang melakukan penganiayaan adalah orang tua, ayah atau ibu tiri, atau anggota keluarga maka dampaknya akan lebih parah daripada yang melakukannya orang yang tidak dikenal.

c. Seberapa parah. Semakin sering dan semakin buruk perlakuan yang diterima anak akan memperparah kondisi anak

d. Berapa lama terjadi. Semakin lama kejadian berlangsung akan semakin meninggalkan trauma yang membekas pada diri anak

e. Jika anak mengungkapkan penganiayaan yang dialaminya, dan menerima dukungan dari orang lain atau anggota keluarga yang dapat mencintai, mengasihi dan memperhatikannya maka kejadiannya tidak menjadi lebih parah sebagaimana jika anak justru tidak dipercaya atau disalahkan

f. Tingkatan sosial ekonomi, anak pada keluarga dengan status sosial ekonomi rendah cenderung lebih merasakan dampak negatif dari penganiayaan anak.

Dalam beberapa kasus, anak-anak yang mengalami penganiayaan tidak menunjukkan gejala-gejala seperti di atas. Banyak faktor lain yang berpengaruh seperti seberapa kuat status mental anak, kemampuan anak mengatasi masalah dan penyesuaian diri. Ada kemungkinan anak tidak mau menceritakan karena takut diancam, atau bahkan dia mencintai orang yang melakukan penganiayaan tersebut. Dalam hal ini anak biasanya menghindari adanya tindakan hukum yang akan menimpa orang-orang yang dicintainya, seperti orang tua, anggota keluarga atau pengasuh.

\section{METODE PENELITIAN}

Penelitian ini dilakukan dengan beberapa tahapan, yaitu:

\section{Desain Penelitian}

Desain penelitian ini merupakan penelitian deskriptif sederhana, dimana variabel penelitian karakteristik responden digambarkan secara rinci pada kejadian kekerasan pada anak.

\section{Populasi, Sampel dan Metode Sampling}


Populasi dalam penelitian ini adalah siswa SD muhammadiyah se kota Malang kelas 3, 4, 5 dan 6, yang diambil secara random dan diperoleh 347 responden dari SD Muhammadiyah 1, 5, 6 dan 9 kota Malang Tempat Penelitian Penelitian ini dilakukan di masing-masing SD Muhammadiyah yaitu 1, 5, 6, dan 9.

\section{Teknik Pengumpulan Data}

Proses pengumpulan data dilakukan dengan cara, membagikan kuesioner pada masing-masing siswa pada tiap kelas dengan waktu yang berbeda. Setelah kuesioner dibagikan, peneliti membacakan pertanyaanpertanyaan serta menjelaskan maksud dari setiap pertanyaan yang tercantum pada kuesioner. Terutama bagi siswa kelas tiga dan empat, peneliti memberikan penjelasan satu persatu pada tiap pertanyaan yang ada di kuesioner sebagaimana terlampir, karena tingkat pemahaman anak yang masih memerlukan pendampingan. Analisis Data

Analisa univariat tiap variabel dari hasil penelitian ini hanya dilakukan perhitungan distribusi frekuensi, kecenderungan tengah, dan normalitas. Terhadap usia, jenis kelamin, dan karakter lainnya.

\section{HASIL DAN PEMBAHASAN}

Pada bab ini akan disajikan deskripsi hasil penelitian serta dibahas dengan penguraian jelas dan diperkuat dengan pustaka yang relevan.

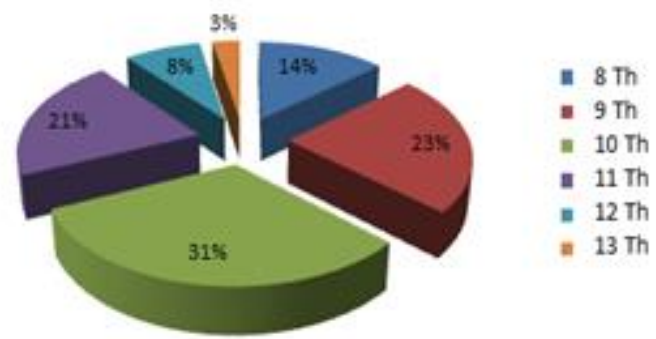

Gambar. 1

Tabulasi Frekuensi Responden Berdasarkan Usia

Berdasarkan Gambar 1, diketahui bahwa mayoritas responden yang mengalami kekerasan berada pada usia 9 tahun (23\%), 10 tahun (31\%) dan 11 tahun (21\%).

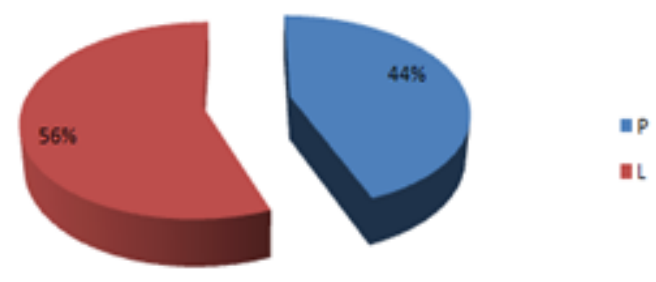

Gambar. 2

Tabulasi frekuensi Responden Berdasarkan Jenis Kelamin

Berdasarkan Gambar 2, karakteristik responden berdasarkan jenis kelamin yang sering mendapatkan kekerasan adalah jenis kelamin laki-laki (56\%), hal ini bisa dilatarbelakangi oleh pengalaman dalam keluarga. Gelles Richard J. (1982) menyatakan Pewarisan kekerasan antar generasi (Intergenerational transmission of violence), dimana anak banyak belajar perilaku kekerasan dari orang tuanya dan ketika tumbuh menjadi dewasa mereka melakukan tindakan kekerasan kepada anaknya pula. 


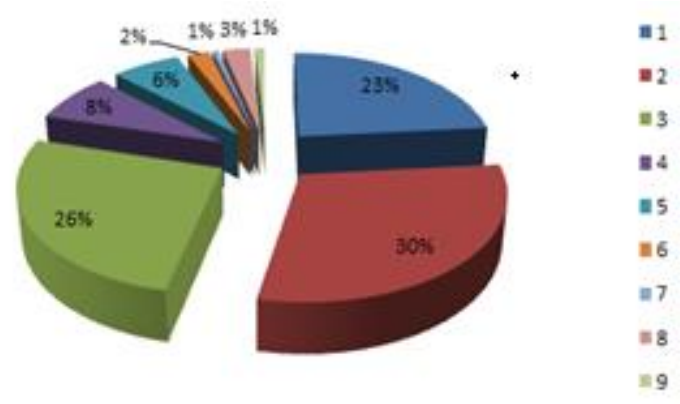

Gambar. 3

Tabulasi Frekuensi Responden Berdasarkan Jumlah Saudara

Berdasarkan Gambar 3, frekuensi responden didasarkan pada jumlah saudara, yang mengalami kekerasan mayoritas berkisar antara anak tunggal sampai tiga bersaudara, yaitu 23-30\%, jumlah saudara turut berpotensi terhadap terjadinya kekerasan, Tipe-tipe keluarga tertentu memiliki resiko yang meningkat untuk melakukan tindakan kekerasan dan pengabaian kepada anak. Misalnya orang tua tunggal lebih memungkinkan melakukan tindakan kekerasan terhadap anak dibandingkan dengan orang tua utuh (Gelles Richard J.(1982).

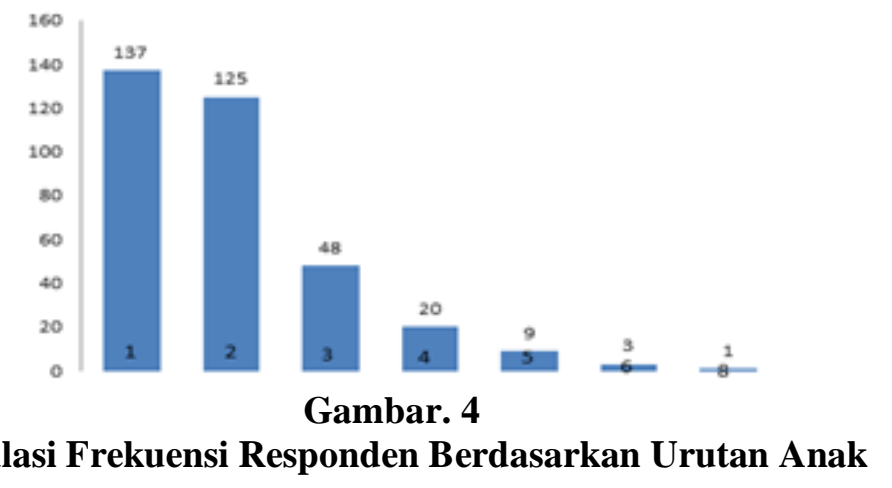

Berdasarkan Gambar 4, mayoritas responden berada pada urutan anak ke 1-3. Tipe-tipe keluarga tertentu memiliki risiko yang meningkat untuk melakukan tindakan kekerasan dan pengabaian kepada anak : ukuran keluarga besar dari rata-rata (a larger than average family size), kelahiran bayi baru (the presence of a new baby), (Gelles Richard J.(1982)

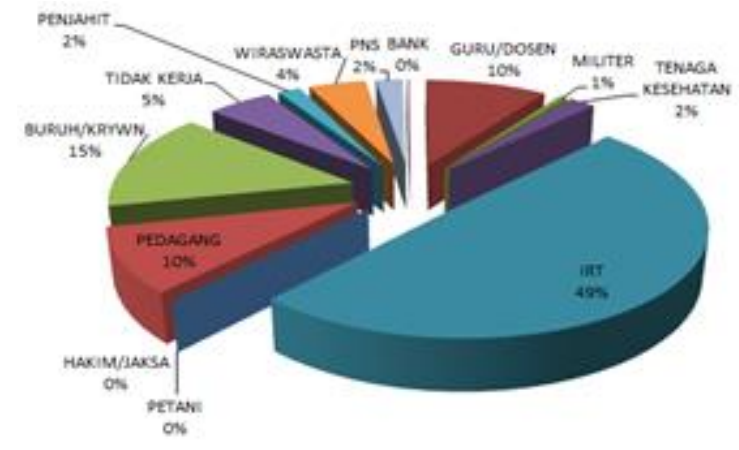

(a)

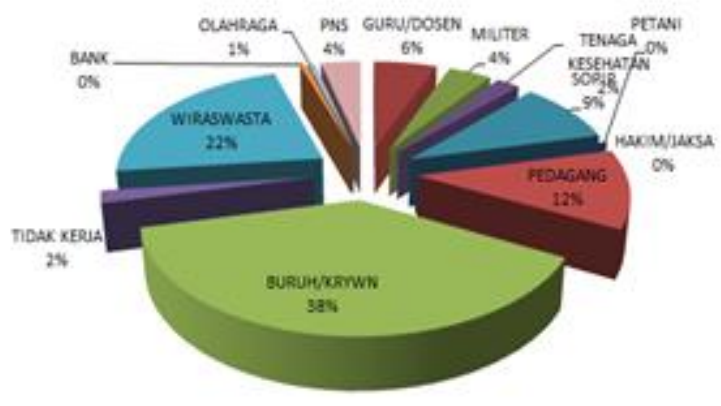

(b)

Gambar. 5

Tabulasi Frekuensi Responden Berdasarkan Pekerjaan Ibu (a) dan Bapak (b)

Berdasarkan data pada Gambar 5, mayoritas orang tua adalah ibu rumah tangga tanpa penghasilan, dan buruh/karyawan. Hal ini merupakan pemicu terjadinya kekerasan. Stress yang ditimbulkan oleh berbagai kondisi sosial meningkatkan risiko kekerasan terhadap anak dalam keluarga. Kondisi-kondisi ini mencakup 
pengangguran (unemployment), penyakit (illness), kondisi perumahan yang buruk (poor housing condition) ukuran keluarga besar dari rata-rata (a larger than average family size), kelahiran bayi baru (the presence of a new baby), orang cacat (disable person) di rumah. Dan kematian (the death) seorang anggota keluarga. Sebagian besar kasus dilaporkan tentang tindakan kekerasan terhadap anak berasal dari keluarga yang hidup dalam kemiskinan. Tindakan kekerasan terhadap anak juga terjadi dalam keluarga kelas menengah dan kaya (Gelles Richard J., 1982).

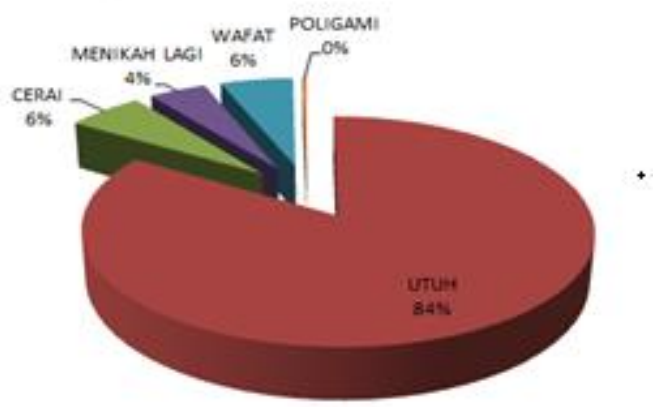

Gambar. 6

\section{Tabulasi Frekuensi Responden Berdasarkan Status Pernikahan Orang tua}

Pada gambar 6, mayoritas responden yang mengalami kekerasan berasal dari pernikahan orang tua yang utuh (64\%), Orang tua tunggal lebih memungkinkan melakukan tindakan kekerasan terhadap anak dibandingkan dengan orang tua utuh. Selain itu, keluarga-keluarga di mana baik suami atau istri mendominasi di dalam membuat keputusan penting, mempunyai tingkat kekerasan terhadap anak yang lebih tinggi. (Gelles Richard J., 1982)

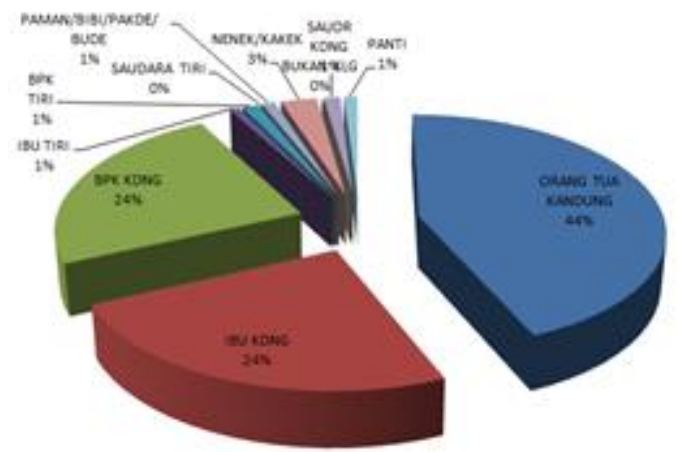

Gambar. 7

Tabulasi Frekuensi Responden Berdasarkan Penanggung Jawab Biaya Pendidikan

Pada Gambar 7, mayoritas biaya pendidikan ditanggung oleh orang tua kandung (46\%), ibu kandung (26\%), ayah kandung (24\%). Tingkatan sosial ekonomi berhubungan erat dengan kejadian kekerasan, anak pada keluarga dengan status sosial ekonomi rendah cenderung lebih merasakan dampak negatif dari penganiayaan anak. Sebagian besar kasus dilaporkan dimana kekerasan terhadap anak berasal dari keluarga yang hidup dalam kemiskinan. Tindakan kekerasan juga terjadi dalam keluarga kelas menengah dan kaya. Tetapi lebih banyak dari keluarga miskin karena beberapa alasan. (Gelles Richard J., 1982).

\section{Kekerasan Fisik}

Suharto (1997), Kekerasan secara fisik adalah penyiksaan, pemukulan dan penganiayaan terhadap anak, dengan atau tanpa menggunakan benda-benda tertentu, yang menimbulkan luka-luka fisik atau 
kematian pada anak. Bentuk luka dapat berupa lecet atau memar akibat persentuhan atau kekerasan benda tumpul, seperti bekas gigitan, cubitan, ikat pinggang, atau rotan.

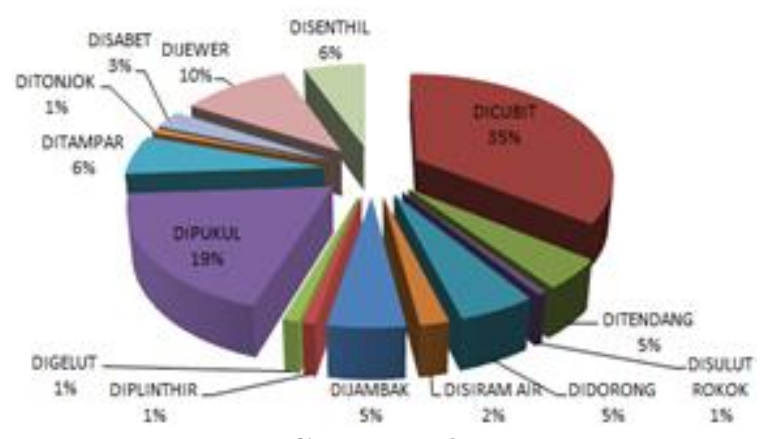

Gambar. 8

\section{Tabulasi Frekuensi Responden Berdasarkan Kekerasan Fisik yang Pernah Diterima}

Kekerasan fisik yang diterima oleh anak mayoritas adalah dicubit (35\%) dan dipukul (19\%) dijewer (10\%) sedangkan dijambak, didorong, ditampar rata-rata 5\%. Hal ini dilatarbelakangi oleh upaya orang tua untuk mendisiplinkan dalam peraturan sehari-hari. Hal ini dibuktikan dengan hasil identifikasi tentang alasan kekerasan yang dilakukan pada anak, diantaranya mayoritas adalah : Terlambat bangun (26\%), bertengkar (20\%) dan tidak sholat (15\%). Kekerasan fisik yang terjadi pada anak tidak sampai menimbulkan perlukaan fisik atau kematian, sehingga dapat dikatakan bahwa kekerasan yang dialami anak hanya terbatas pada kekerasan ringan yang bertujuan mendisiplinkan anak, sebagaimana dalam gambar 4.10 dan 4.11,

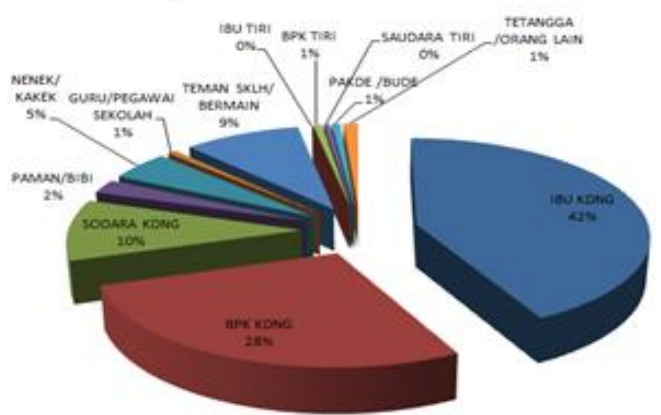

Gambar. 10

Tabulasi Frekuensi Responden Berdasarkan Pelaku Kekerasan

Pada gambar 4.10, Pelaku kekerasan yang diterima anak, mayoritas adalah ibu kandung (42\%) menyusul bapak kandung (28\%) selanjutnya saudara kandung (10\%) dan teman bermain (9\%). Purbani (2003) mengatakan, kekerasan dalam rumah tangga baik dilakukan oleh suami kepada istrinya atau orang tua terhadap anaknya bisa berbentuk fisik dan non fisik. Banyak orang tua ingin menjadi orang tua yang baik, tapi lepas kendali dalam mengatasi perilaku anak. Sangat sulit dibayangkan bagaimana orang tua dapat melukai anaknya, seringkali penyiksaan fisik adalah hasil dari hukuman fisik yang bertujuan menegakkan disiplin, yang tidak sesuai dengan usia anak. 


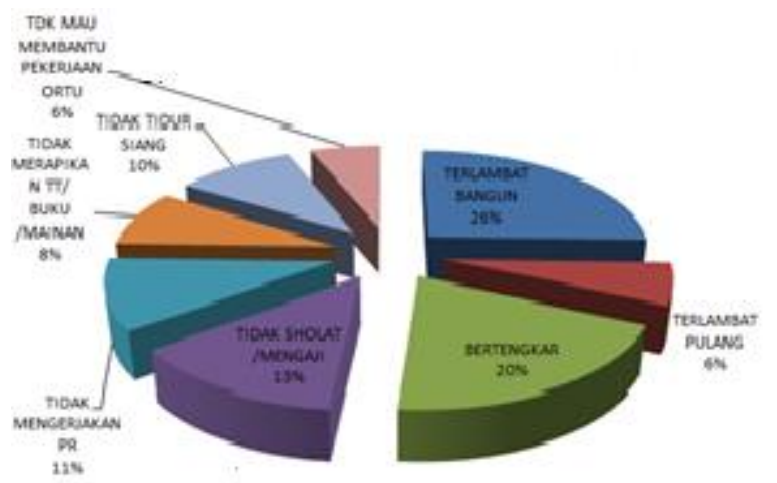

Gambar. 11

Tabulasi Frekuensi Responden Berdasarkan Alasan Kekerasan

Pada Gambar 11, mayoritas alasan kekerasan dilakukan terhadap anak adalah: terlambat bangun (26\%), bertengkar (20\%) dan tidak sholat (15\%). Seringkali penyiksaan fisik adalah hasil dari hukuman fisik yang bertujuan menegakkan disiplin, yang tidak sesuai dengan usia anak. Banyak orang tua ingin menjadi orang tua yang baik, tapi lepas kendali dalam mengatasi perilaku anak. Terjadinya kekerasan fisik pada anak umumnya dipicu oleh tingkah laku anak yang tidak disukai orang tuanya, seperti anak nakal.

\section{Kekerasan Verbal}

Kekerasan pada anak biasanya berupa perilaku verbal dimana pelaku melakukan pola komunikasi yang berisi penghinaan, ataupun kata-kata yang melecehkan anak. Pelaku biasanya melakukan tindakan mental abuse, menyalahkan , melabeli, atau juga mengkambing hitamkan. (Terry E. Lawson (dalam huraerah, 2007).

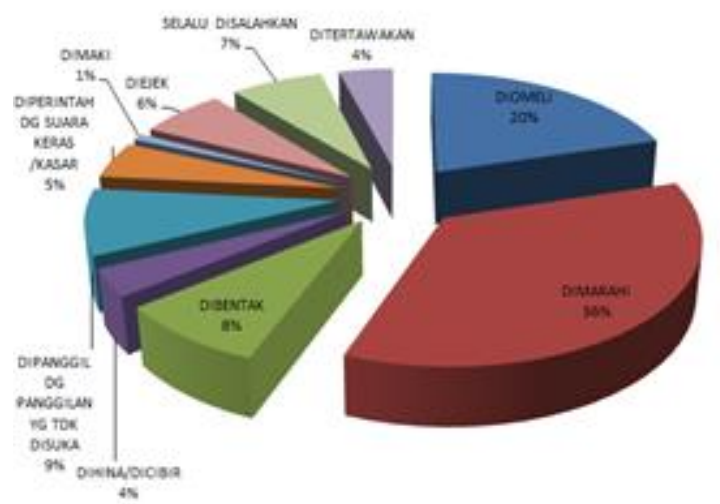

Gambar. 12

Tabulasi Frekuensi Responden Berdasarkan Kekerasan Verbal yang Pernah Diterima

Dari hasil penelitian, didapatkan data kekerasan verbal yang sering diterima mayoritas dimarahi (36\%), diomeli (20\%) dan dipanggil dengan panggilan buruk (9\%), dibentak (8\%), selalu disalahkan (7\%) juga menduduki prosentase yang patut diperhitungkan. Kekerasan verbal pada anak di kota Malang yang mayoritas dimarahi dan diomelin, adalah sebagai bentuk upaya orang tua mendisiplinkan anak dan bukan bentuk kekerasan verbal yang sesungguhnya. Namun sebagian kecil terdapat beberapa orang tua yang melakukan kekerasan verbal dalam bentuk memanggil dengan panggilan buruk, membentak dan menyalahkan anak. Sehingga bisa dikatakan kekerasan verbal yang terjadi pada anak di kota Malang tidak terlalu berat. 


\section{Kekerasan Emosi}

Penyiksaan emosi adalah semua tindakan merendahkan atau meremehkan orang lain. Anak yang terus menerus dipermalukan, dihina, diancam atau ditolak akan menimbulkan penderitaan yang tidak kalah hebatnya dari penderitaan fisik (Lawson, 2007).

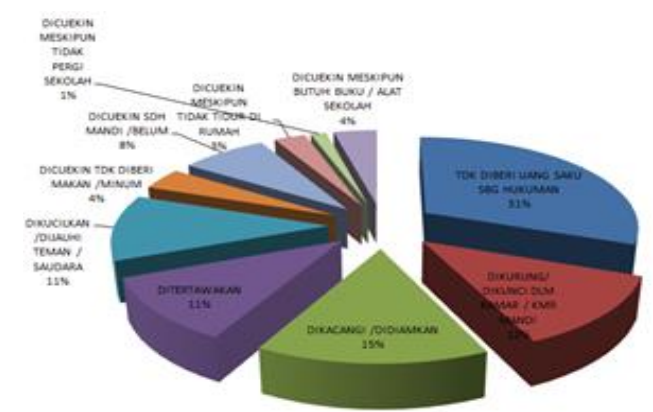

Gambar. 13

Tabulasi Frekuensi Responden Berdasarkan Kekerasan Emosional yang Pernah Diterima

Berdasarkan hasil penelitian, didapatkan hasil mayoritas adalah tidak diberi uang saku sebagai hukuman (31\%), sedangkan rata-rata berada di rentang 11-15\% adalah diamkan, dikurung di kamar mandi, ditertawakan dan dikucilkan. Bentuk kekerasan emosi yang terjadi pada anak di kota Malang merupakan upaya pendisiplinan orang tua pada anak. Hal ini teridentifikasi bahwa mayoritas anak tidak diberi uang saku. Namun ada beberapa temuan bentuk kekerasan emosional berupa didiamkan, dikurung di kamar mandi, ditertawakan dan dikucilkan yang sifatnya minoritas, sehingga bisa dikatakan bahwa bentuk kekerasan emosional pada anak di kota Malang tidak berat.

\section{Kekerasan Seksual}

Kekerasan seksual dapat berupa perlakuan pra-kontak seksual antara anak dengan orang yang lebih besar (melalui kata, sentuhan, gambar visual, exhibitionism maupun perlakuan kontak seksual secara langsung antara anak dengan orang dewasa (incest, perkosaan, eksploitasi seksual. (Suharto (1997).

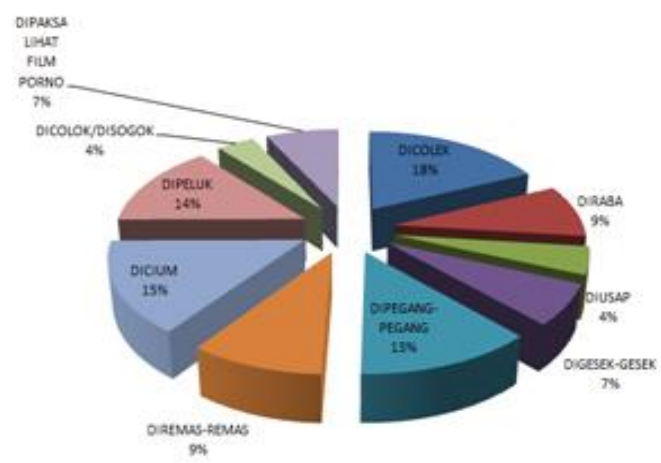

\section{Gambar. 14}

Tabulasi Frekuensi Responden Berdasarkan Kekerasan Seksual yang Pernah Diterima

Berdasarkan hasil penelitian menunjukkan terdapat beberapa responden mengalami dicolek, dipegangpegang, dipeluk dan dicium dengan rentang prosentase 13\% - 18\%. Pada kekerasan lain, meskipun prosentase kecil, namun kekerasan ini memprihatinkan diantaranya diraba, digesek-gesek, diremas-remas, dipaksa nonton video porno, bahkan dicolok/disogok berada pada rentang 9\%-4\%. Meskipun rata-rata prosentase kecil, namun menunjukkan adanya potensi kekerasan seksual, sehingga dapat dinyatakan terdapat potensi kekerasan seksual. Potensi ini didukung oleh data tentang bagian tubuh yang mendapatkan kekerasan seksual dan ketidak beranian anak untuk melaporkan kejadian pada orang terdekat setelah 
mendapatkan kekerasan, sehingga berpotensi untuk terjadi secara berulang. Hal ini dibuktikan pada Gambar 15 dan 16.

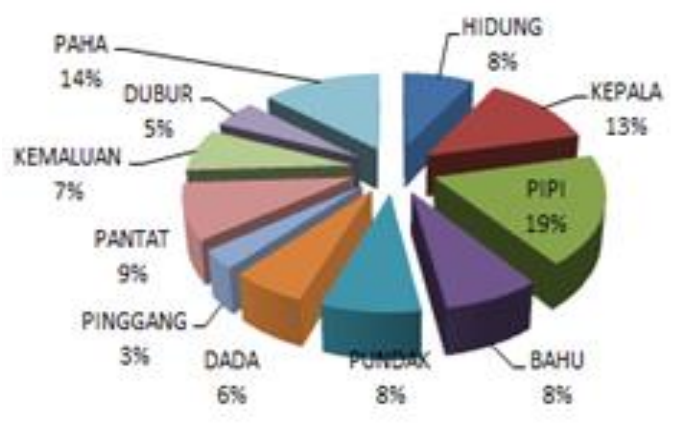

Gambar. 15

\section{Tabulasi Frekuensi Bagian Tubuh Responden yang mendapat Kekerasan Seksual}

Pada Gambar 15, menunjukkan mayoritas bagian tubuh yang mendapat kekerasan seksual adalah pipi $(19 \%)$ dan paha (14\%), namun meskipun kecil bagian tubuh yang memprihatinkan karena mendapat kekerasan seksual adalah kemaluan (7\%) dan dubur (5\%). sexual abuse adalah setiap perbuatan yang berupa pemaksaan hubungan seksual, pemaksaan hubungan seksual dengan orang lain untuk tujuan komersial dan atau tujuan tertentu. Mayer (dalam Tower, 2002) menyebutkan kategori sexual molestation (penganiayaan), yaitu semua hal yang berkaitan dengan menstimulasi pelaku secara seksual.

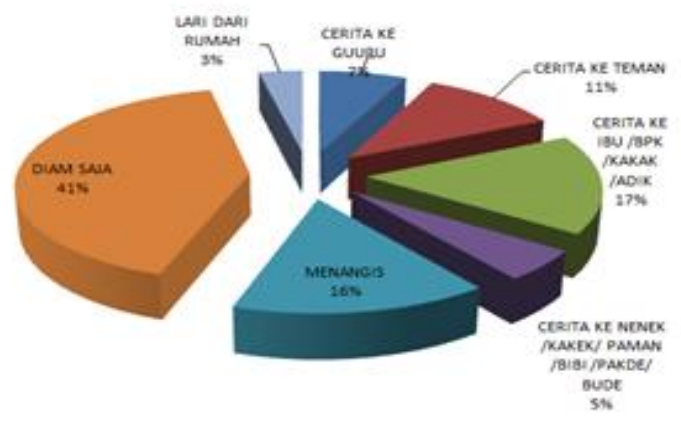

Gambar. 16

Tabulasi Frekuensi Tindakan Responden Setelah Mendapat Kekerasan Seksual

Pada Gambar 16, mayoritas tindakan anak setelah mendapat kekerasan adalah diam (41\%) dan menangis (16\%), diikuti dengan bercerita pada orang tua (17\%) cerita ke teman (11\%) dan guru (9\%). Jika anak mengungkapkan penganiayaan yang dialaminya, dan menerima dukungan dari orang lain atau anggota keluarga yang dapat mencintai, mengasihi dan memperhatikan maka kejadiannya tidak menjadi lebih parah sebagaimana jika anak justru tidak dipercaya atau disalahkan. Ada kemungkinan anak tidak mau menceritakan karena takut diancam, atau bahkan dia mencintai orang yang melakukan penganiayaan tersebut dan anak biasanya menghindari adanya tindakan hukum yang akan menimpa orang-orang yang dicintainya, seperti orang tua, anggota keluarga atau pengasuh. (Gelles Richard J., 1982).

Kekerasan berarti penganiayaan, penyiksaan atau perlakuan salah. Menurut WHO (dalam bagong S, dkk, 2000), kekerasan adalah penggunaan kekuatan fisik dan kekuasaan, ancaman atau tindakan terhadap diri sendiri, perorangan atau sekelompok orang atau masyarakat yang mengakibatkan atau kemungkinan besar mengakibatkan memar/trauma, kematian, kerugian psikologis, kelainan perkembangan atau perampasan hak. Awal mulanya istilah tindak kekerasan pada anak atau child abuse dan neglect dikenal dari dunia kedokteran, sekitar tahun 1946, caffey-seorang radiologist melaporkan kasus cedera yang berupa gejala-gejala klinik seperti patah tulang panjang yang majemuk (multiple fractures) pada anak-anak atau 
bayi disertai perdarahan subdural tanpa mengetahui sebabnya (unrecognized trauma). Dalam dunia kedokteran. Istilah ini dikenal dengan istilah Caffey Syndrome (Ranuh, 1999). Barker (dalam hurairah, 2007) mendefinisikan Child abuse merupakan tindakan melukai berulang-ulang secara fisik dan emosional terhadap anak yang ketergantungan, melalui desakan hasrat, hukuman badan yang tidak terkendali, degradasi dan cemoohan permanen atau kekerasan seksual.

Pada hasil penelitian tidak teridentifikasi adanya kekerasan sebagaimana pada teori. Adanya kekerasan baik fisik, verbal, emosi yang ditemukan merupakan bentuk upaya orang tua mendisiplinkan anak dalam peraturan sehari-hari. Sebagai bukti dalam kekerasan fisik, mayoritas anak dicubit ketika anak terlambat bangun pagi, bertengkar dan tidak sholat. sedangkan pada kekerasan verbal mayoritas anak dimarahi dan diomeli juga dalam rangka mendisiplinkan anak. Pada kekerasan emosi mayoritas anak tidak diberi uang saku sebagai hukuman.

Pada temuan kekerasan seksual pada anak menunjukkan adanya potensi dalam bentuk dicolek, dipegang-pegang, dipeluk dan dicium, dengan prosentase lebih besar dari pada tindakan diraba, digesekgesek, diremas - remas, dipaksa nonton video porno, bahkan dicolok/disogok. Meskipun prosentase kecil namun tindakan tersebut memerlukan kewaspadaan karena dapat menjadi pencetus terjadinya kekerasan seksual lebih serius.

\section{KESIMPULAN}

Karakteristik responden yang mayoritas mengalami kekerasan di antaranya usia yang muda, jumlah saudara antara 1-3, dan anak laki-laki, serta urutan anak pertama sampai ketiga. Kondisi perekonomian keluarga yang kurang meskipun status pernikahan utuh juga menduduki mayoritas pada anak yang mendapat kekerasan. Kondisi perekonomian ini berdampak pula pada biaya pendidikan yang turut berkontribusi pada kejadian kekerasan.

Pada jenis kekerasan, kekerasan fisik yang banyak diterima oleh anak mayoritas adalah dicubit (35\%) dan dipukul (19\%) dijewer (10\%) sedangkan dijambak, didorong, ditampar rata-rata 5\%. Pada kekerasan verbal yang sering diterima mayoritas dimarahi (36\%), diomeli (20\%) dan dipanggil dengan panggilan buruk (9\%), dibentak (8\%), selalu disalahkan (7\%) juga menduduki prosentase yang patut diperhitungkan. Pada kekerasan emosional yang pernah diterima anak mayoritas adalah tidak diberi uang saku sebagai hukuman (31\%), sedangkan rata-rata berada pada rentang 11-15\% adalah; didiamkan, dikurung di kamar mandi, ditertawakan dan dikucilkan. Sedangkan kekerasan seksual frekuensi tersering yang berada dalam rentang 13\% - 18\% adalah: dicolek, dipegang-pegang, dipeluk dan dicium. pPda kekerasan seksual yang lain, meskipun prosentase kecil, namun kekerasan ini memprihatinkan diantaranya: digesek-gesek, dipaksa nonton video porno, diremas-remas, diraba, bahkan dicolok/disogok berada pada rentang 4\% - 9\%.

Pelaku kekerasan lebih banyak dilakukan oleh orang terdekat yaitu ibu, bapak, saudara dan teman, dengan lebih banyak alasan karena upaya pendisiplinan anak dalam pengasuhan, sedangkan tindakan anak setelah mendapat kekerasan lebih banyak diam dan menangis, diikuti dengan bercerita pada orang terdekat, orang tua, teman dan guru.

\section{Daftar Pustaka}

Dalyono, M.Drs. (1997). Psikologi pendidikan. Jakarta: P.T. Rineka Cipta

Ginott, Halim G., Dr. (2001). Between parents and child. Jakarta: P.T. Gramedia Pustaka Utama

Gunarsa, Singgih D., dkk Perkembangan anak dan Remaja. Jakarta: P.T. BPK Gunung Mulia

Arif Gosita. 2004. Masalah Korban Kejahatan. Jakarta: PT Bhuana Ilmu Populer.

Edi Abdullah Mahadar dan Husni Thamrin. 2010. Perlindungan Saksi dan Korban Dalam Sistem Peradilan Pidana. Surabaya: Putra Media Nusantara.

F.X. Rudy Gunawan. 2003. Mengebor Kemunafikan: Inul, Sex dan Kekuasaan. Yogyakarta: Kawan Pustaka.

Haris. 2011. "Analisa Kriminologis terhadap Prostitusi Yang Dilakukan Mahasiswi di Malang." Malang: Universitas Brawijaya.

-------------, Perlindungan Anak, Akademika Presindo, Jakarta, 1983

Hadisuprarto, Juvenille Delinquency (Pemahaman dan Penanggulangannya), UNDIP, Semarang, 1996. 